\title{
Yoga for Older Adults -Hypothesis and Tools for Yoga Teachers
}

\author{
Neela K Patel ${ }^{1 *}$ and Sreedhara Akkihebbalu ${ }^{2}$ \\ ${ }^{1}$ Department of Family \& Community Medicine, Joe \& Teresa Long School of Medicine, USA \\ ${ }^{2}$ President, Kaveri Natya Yoga, USA
}

Submission: February 12, 2018; Published: March 14, 2018

*Corresponding author: Neela K Patel, Associate Professor \& Chief Division of Geriatrics \& Palliative Care, Department of Family \& Community Medicine, Joe \& Teresa Long School of Medicine, UT Health San Antonio, USA, Email: PATELN4@uthscsa.edu

\section{Introduction}

As adults age, changes in their lives and bodies may impair their ability to move effectively and safely [1]. The effects of chronic health conditions and geriatric syndromes may limit mobility and increase their dependence on others to assist them in activities of daily living (ADL's) [1]. Although strong evidence indicates that physical activity can prevent impairment and maintain function and health related quality of life [2,3], only 10 percent of Americans between 65-74 years report engaging in activities that promote strength and endurance two or more days/week $[3,4]$.

\section{Decreased physical inactivity and its effects among older adults}

Decreased physical capacity (e.g., muscular strength and endurance, flexibility, agility, and balance) leads to impairment in functional tasks (e.g., standing up from a seated position) that may lead to difficulties in maintaining personal and social roles $[5,6]$. Because quality of life in later years depends largely on the ability to independently engage in self-selected activities [3], physicians must encourage older patients to actively participate in physical activities.

Many older adults refrain from participating in evidencebased programs for physical activity (e.g., "Active Start", "Enhance Fitness") [4]. Some elders report that exercise programs are designed for more functionally able persons. Another potential barrier is that many exercise programs are based on "one size fits all" approach [7]. Resnick suggests interventions for older adults could improve regular exercise by establishing goals tailored to function and physical level [8].

\section{Positive effects of exercise}

The National Institute on Aging recommends four different types of exercises for older adults: endurance, balance, strengthening, and flexibility $[9,10]$. Because yoga involves each of these recommended components of exercise it may improve functional and physiological outcomes. In our recent systematic review and meta-analysis of randomized trials of yoga in older adults [11] we found yoga's benefits varied due to many small trials of mixed quality and limited exploration of physiological mechanisms. Thus, researchers must determine the extent to which yoga is effective across a range of outcomes for older adults. Understanding yoga's benefits and mechanisms, how they differ in older adults, and how they can be tailored to individual needs are important next steps in developing effective yoga interventions $[11,12]$.

\section{Proposed logic model to explain how yoga benefits older adults}

We propose the following logic model as the hypothesis for explaining the different mechanisms by which yoga is thought to benefit older adults Figure 1.

Adapting yoga for older adults to positively address the different types of health

Yoga teachers should remember two principles of functional health as they adapt their instruction for older adults:

A. Functional health and independence - aging in place - is the main goal for all seniors.

B. Functional health depends on five categories of health: physical, mental/psychosocial, economic, and medical and spiritual.

The Table 1 below lists the different types of health and indicates the changes older adults may be undergoing.

\section{Physical changes and suggestions to address them during yoga instruction}

As adults age, they may experience specific physical changes that limit their ability to practice yoga. Thinking of how different parts of an older student's body may change can help yoga teachers adapt their instruction in particular ways that allow the student to continue in their yoga classes. For each part of the body and its possible physical change, Table 2 suggests specific ways to address the change. 


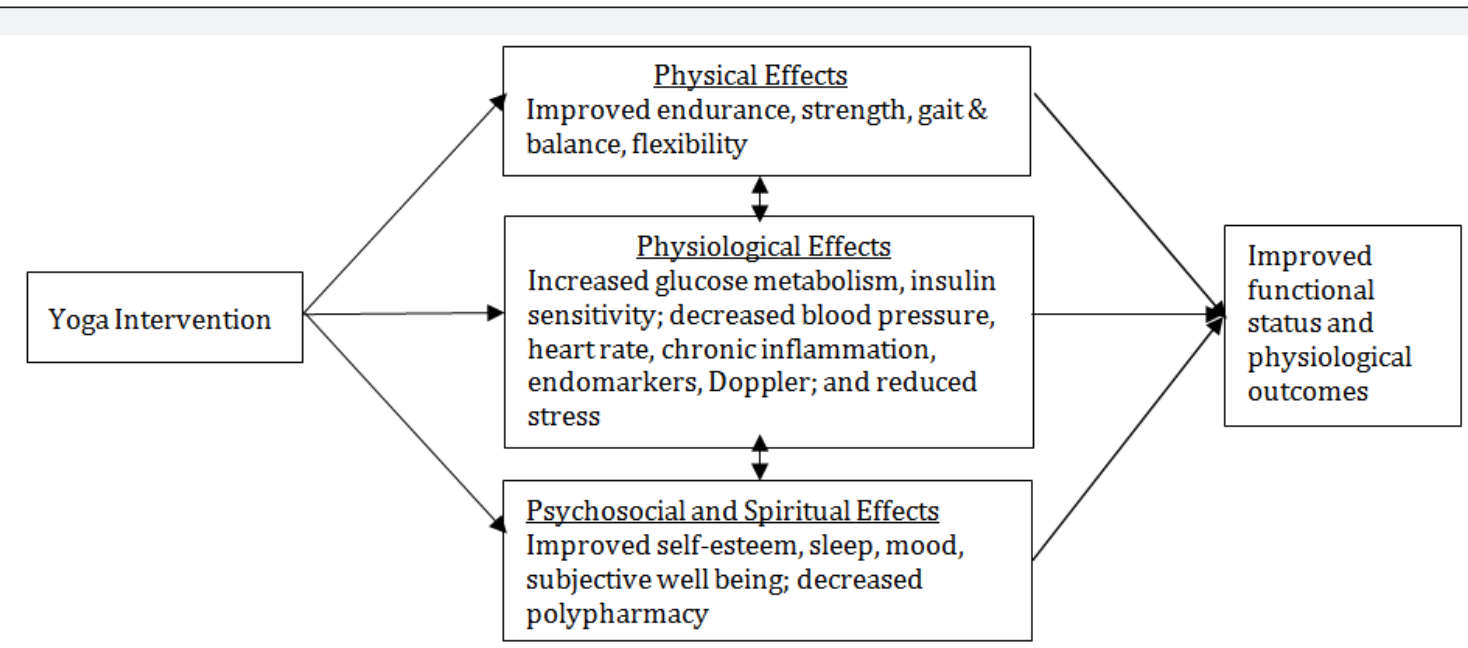

Figure 1: Logic Model. Hypothesized pathway by which yoga interventions may enhance functional status and physiological outcomes.

Table 1: Types of health and changes older adults may experience.

\begin{tabular}{|c|c|}
\hline Physical health & Head to toe changes discussed in next section \\
\hline Mental health & $\begin{array}{c}\text { Loneliness, depression, grief, cognitive impairment and problems with } \\
\text { memory that affect functional health and caring for themselves }\end{array}$ \\
\hline Social health & $\begin{array}{c}\text { Lose spouse, family, friends; have change in social status or role (may } \\
\text { further affect mental and psychological health); change homes; and } \\
\text { move to independent living communities }\end{array}$ \\
\hline Economic health & $\begin{array}{c}\text { Live on a fixed income and social security or savings, cost of living } \\
\text { keeps increasing }\end{array}$ \\
\hline Medical health & $\begin{array}{c}\text { Have multiple chronic conditions and take many medications with } \\
\text { results and side effects that lower balance and increase risk for falls. }\end{array}$ \\
\hline Spiritual health & Ultimate goal for all \\
\hline
\end{tabular}

Table 2: Physical changes in older adults and suggestions on how to address them in yoga instruction.

\begin{tabular}{|c|c|}
\hline Part of Body: Possible Change & Suggestion to Address the Change \\
\hline $\begin{array}{l}\text { Brain: Cognitive impairment or problems with memory (especially } \\
\text { short term) }\end{array}$ & $\begin{array}{l}\text { Speak in short sentences, say one thing at a time and give them time to } \\
\text { understand, and write instructions in simple steps. }\end{array}$ \\
\hline Eyes: Cataracts or macular degeneration & $\begin{array}{l}\text { Stand } 3 \text { feet or closer to them so they can see what you are showing } \\
\text { them to do. }\end{array}$ \\
\hline $\begin{array}{l}\text { Ears: Decreased hearing and increased sensitive to high frequency } \\
\text { sounds }\end{array}$ & $\begin{array}{l}\text { Speak in a lower tone (i.e., not louder) and stand in front of them so } \\
\text { they can read your lips. }\end{array}$ \\
\hline $\begin{array}{l}\text { Joints in General: Osteoarthritis--unable to firmly grip objects because } \\
\text { of the arthritic changes }\end{array}$ & $\begin{array}{l}\text { Be wary of twists (e.g. do gentle chair twists) and tell them to avoid } \\
\text { being too aggressive. }\end{array}$ \\
\hline Lungs: Decreased expansion & Use the belt to open the chest and improve breathing. \\
\hline Heart: Those with decreased cardiac output & Require them to get a clearance from a physician. \\
\hline $\begin{array}{l}\text { Gastrointestinal/Stomach: Eat smaller meals more frequently; } \\
\text { constipation }\end{array}$ & $\begin{array}{l}\text { Tell them not to eat } 1 \text { and a half hours before class instead of two } \\
\text { and half hours. and half hours. Suggest poses that may help with } \\
\text { constipation. }\end{array}$ \\
\hline Kidneys/Urinary System: Urination slows down. & Ask them to empty their bladder before starting class. \\
\hline Nerves: Neuropathy or unable to feel sensations well, especially in feet & Use alternate standing poses with chair yoga. \\
\hline $\begin{array}{l}\text { Musculoskeletal System in General: Frailty due to decreased bone and } \\
\text { muscle mass }\end{array}$ & Start low and go slow. \\
\hline
\end{tabular}


Table 3: Sample sequence of poses with tips for adaptations to various individual abilities.

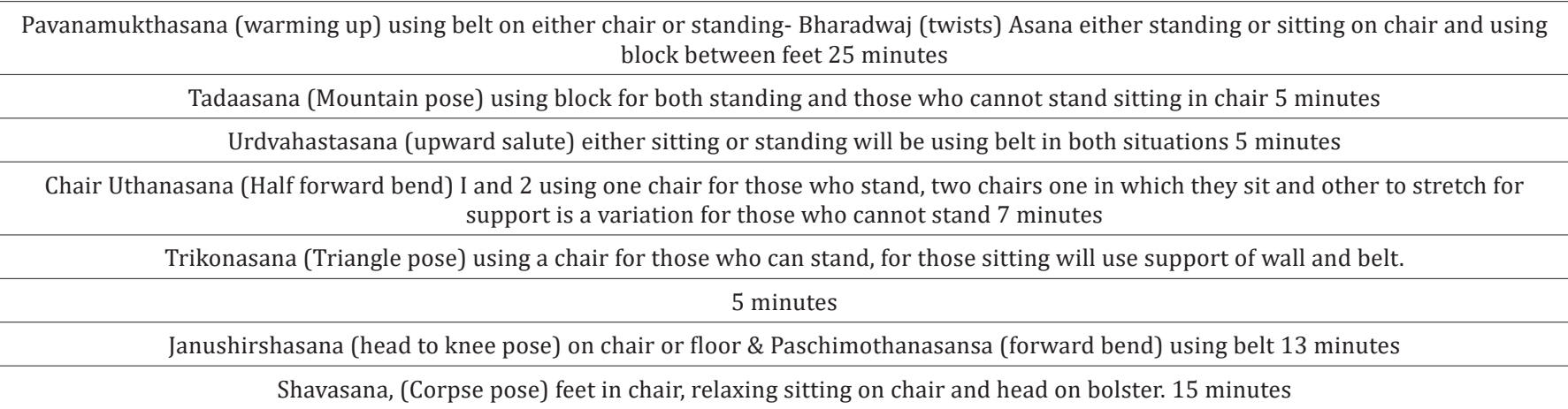

\section{Types of yoga and asana adaptation for older adults}

There are various types of yoga that are practiced, for the changes in our bodies that occur as we age here are some ways by which yoga asana's can be adapted.

A. Teach Iyengar yoga to older adults because it uses props and can be tailored to an individual's body.

B. Employ as many props (e.g., belts, blocks, chairs, bolsters) as needed for the position.

C. Use alternate standing poses with sitting and lying down on the floor only for those who can. Use low benches for those who cannot lie down.

D. Have beginners hold each pose for about 30 to 45 seconds. For more advanced students, increase the time to a minute or longer.

E. Give breaks between poses.

F. Use asanas adapted standing poses with the chair for support -uthanasana, adhomukhosvanasa, trikonasa.

G. Use pavanmukhthasana series either sitting in chair or lying down

H. Use gentle twists.

I. Avoid inversions and back bends.

J. Be cautious while using forward bending. Use lot of support and props.

K. Focus more on breathing and guided shavasana.

\section{Sample adapted yoga session sequence for older adults}

Yoga for older adults needs to be tailored to the invidividual and in a class you may have individuals with varying needs and abilities. The Table 3 above is a sample sequence of poses with tips for adaptations to various individual abilities.

\section{References}

1. (2018) Centers for disease control and prevention. The state of aging and health in America, 2013.

2. Chodzko Zajko WJ, Proctor DN, Fiatarone Singh MA, Minson CT, Nigg CR, et al. (2009) American college of sports medicine position stand. exercise and physical activity for older adults. Med Sci Sports Exerc 41(7): 1510-1530.

3. Institute of Medicine, Board on Health Care Services (2008) Retooling for an aging America: Building the health care workforce.

4. Carlson SA, Fulton JE, Schoenborn CA, Loustalot F (2010) Trend and prevalence estimates based on the 2008 Physical Activiy Guidelines for Americans. Am J Prev Med 39(4): 305-313.

5. Gill TM, Allore H, Guo Z (2003) Restricted activity and functional decline among community-living older persons. Arch Intern Med 163(11): 1317-1322.

6. Guralnik JM, Ferrucci L (2003) Assessing the building blocks of function: utilizing measures of functional limitation. Am J Prev Med 25(3 Suppl 2): 112-121.

7. Tucker JM, Welk GJ, Beyler NK (2011) Physical activity in U.S.: adults compliance with the physical activity guidelines for Americans. Am J Prev Med 40(4): 454-461.

8. Resnick B, D’Adamo C (2011) Factors associated with exercise among older adults in a continuing care retirement community. Rehabil Nurs 36(2): 47-53, 82.

9. Resnick B (2005) Across the aging continuum: motivating older adults to exercise. Adv Nurse Pract 13(9): 37-40.

10. Physical Activity Guidelines Advisory Committee report (2008) To the Secretary of Health and Human Services. Part A: executive summary. Nutr Rev 67(2): 114-120.

11. Patel NK, Newstead AH, Ferrer RL (2012) The effects of yoga on physical functioning and health related quality of life in older adults: a systematic review and meta-analysis. J Altern Complement Med 18(10): 902-917.

12. Patel NK, Akkihebbalu S, Espinoza SE, Chiodo LK (2011) Perceptions of community based yoga intervention for older adults. Activities, Adaptation and Aging 35(2): 151-163. 
This work is licensed under Creative Commons Attribution 4.0 License

DOI: 10.19080/JYP.2018.04.5555632

\section{Your next submission with Juniper Publishers} will reach you the below assets

- Quality Editorial service

- Swift Peer Review

- Reprints availability

- E-prints Service

- Manuscript Podcast for convenient understanding

- Global attainment for your research

- Manuscript accessibility in different formats ( Pdf, E-pub, Full Text, Audio)

- Unceasing customer service

Track the below URL for one-step submission https://juniperpublishers.com/online-submission.php 